\title{
A framework for examining social stress and susceptibility to air pollution in respiratory health
}

\author{
Um sistema para examinar o estresse social \\ e a suscetibilidade à poluição do ar na saúde respiratória
}

Jane Ellen Clougherty ${ }^{1}$

Laura Diane Kubzansky ${ }^{2}$
This article was originally published by Environ $\mathrm{H}$ ealth Perspect 117:1351-1358 (2009). doi:10.1289/ ehp.0900612 available via http://dx.doi.org/ [Online $12 \mathrm{M}$ ay 2009] and is part of the scientific collaboration between Cien Saude Colet and EH P. Theauthors declarethey haveno competing financial interests.

${ }^{1}$ Department of Environmental Health. Landmark Building, 4th Floor West, Boston, M A 02215 USA.

jcloughe@hsph.harvard.edu ${ }^{2}$ Department of Society, Human Development, and $\mathrm{H}$ ealth, $\mathrm{H}$ arvard School of Public H ealth.
Abstract There is growing interest in disentangling the health effects of spatially clustered social and physical environmental exposures and in exploring potential synergies among them, with particular attention directed to the combined effects of psychosocial stress and air pollution. Both exposures may beelevated in lower-incomeurban communities, and it has been hypothesized that stress, which can influence immune function and susceptibility, may potentiate the effects of air pol-lution in respiratory disease onset and exacerbation. In this paper, we review the existing epidemiologic and toxicologic evidence on synergistic effects of stressand pollution, and describethephysiologic effects of stress and key issues related to measuring and evaluating stress as it relates to physical environmental exposures and susceptibility. Finally, we identify some of the major methodologic challenges ahead as we work toward disentangling the health effects of clustered social and physical exposures and accurately describing the interplay among these exposures. As this research proceeds, we recommend careful attention to the relative temporalities of stress and pollution exposures, to non-linearities in their independent and combined effects, to physiologic pathways not elucidated by epidemiologic methods, and to the relative spatial distributions of social and physical exposures at multiple geographic scales.

Key words Air pollution, Social stress, Spatial analysis, Synergistic effects, U rban community health
Resumo Há um crescente interesse em esclarecer os efeitos na saúde deexposiçõesfísicas esociais de agrupamentos espaciais e em explorar suas potenciais sinergias, com atenção especial aos efeitos do estresse psicossocial epoluição do ar. Ambas as exposições podem ser el evadas em comunidades urbanas de baixa renda; há hipótese de que o estresse, que pode influenciar a função imunológica e a suscetibilidade, possa potencializar os efeitos da poluição do ar no início e no agravamento de doenças respiratórias. Analisamos as evidências epidemiológi cas e toxicológicas sobre os efeitos sinergéticos do estresse e poluição. Descrevemos os efeitos fisiológicos do estresse e questões-chave relacionadas à sua medição e avaliação em relação à suscetibilidadee exposição ambiental física. I dentificamos alguns dos principais desafios metodológicos à medida que esclarecemos os efei tos à saúde de exposições de agrupamento físicos esociais e descrevemos a interação entre essas exposições. Recomendamos especial atenção às relativas temporal idades das exposi ções ao estresse e poluição, à não-linearidade em seus efeitos independentes e combinados, aos caminhos fisiológicos não elucidados pelos métodos epidemi ológi cos eà distribuição espacial relativa de exposições sociais e físicas em múlti plas escalas geográficas.

Palavras-chave Poluição do ar, Estresse social, A nálise espacial, Efei tos sinergéticos, Saúde da comunidade urbana 
There is growing interest within environ-mental health in disentangling effects of clus-tered social and environmental exposures and exploring potential synergies among these exposures ${ }^{1-6}$. This interest stems from the observation that social stressors (i.e., violence, poverty) and environmental exposures (i.e., traffic-related and industrial air pollution) are often spatially correlated and may cluster in lower-income communities, often in locations with lower property values along highways and industrial corridors ${ }^{7,8}$. Traffic-related air pollution is a complex chemical mix ${ }^{9}$, often spatially associated with noise, poverty, and other stressors ${ }^{10}$. Social stressors may lead to poor health outcomes directly or may increase susceptibility to physical exposures, such as air pollution, through alterations in immunefunction and biological systems $\mathrm{s}^{11}$. Thus, the most pollution exposed communities may also be more susceptible because of higher prevalence of social stressors ${ }^{12}$. This potential for spatial confounding and effect modification by social stressors presents a challengeto air pollution epidemiology. Disentangling social and physical environmental risks ${ }^{13}$, understanding synergies among these exposures, and identifying modifiable exposures are particularly important for understanding how best to protect susceptible populations and improveoverall population health.

There is significant evidence linking trafficrelated pollution exposure to respiratory illness. Chronic exposure to traffic-related and particulate air pollution among adults has been linked to upper respiratory tract inflammation ${ }^{14}$, chronic obstructive pulmonary disease (COPD) ${ }^{15}$, lung cancer ${ }^{16}$, and prematuremortality ${ }^{17,18}$. In children, traffic-related pollution exposures, often indicated by residential proximity to major roads, has been associated with airway hyperresponsiveness ${ }^{19}$, wheeze ${ }^{20}$, asthma ${ }^{21}$, reduced lung function $^{22}$, and asthma-related hospitalizations ${ }^{23,24}$. Thereis now increased interest in understanding car-diovascular effects ${ }^{25,26}$, identifying causal constituents ${ }^{27}$, and characterizing susceptible subpopulations ${ }^{5}$.

Psychological stress results when external demands exceed an individual's perceived abilities and resources to meet those demands ${ }^{28}$ and has been linked to respiratory disease and other illness. Limited but growing epidemiologic evidence indicates that psychological stress may also alter susceptibility to physical exposures, such as air pollution. This work examined social-environmental interactions in respiratory and cardiovascular disease, such as stress-related modifica- tion of traffic-related air pollution effects on asthma etiology ${ }^{29}$ or exacerbation ${ }^{30}$. There is also evidence of stress-related modification in the relationship between bone lead level and hypertension among older men ${ }^{31}$. In the same data set, we recently identified modification by stress in the relation between bone lead and heart rate variability (unpublished data by Clougherty JE, Peters JL, Schwartz J, Kubzansky L). One possible pathway for these differential susceptibilities is allostatic load"1. Allostasis (literally, "achieving stability through change") refers to the body's ability to adapt to transient stressors and exposures. Over time, chronic psychological stress and mal adaptive behaviors (e.g., poor diet, sleep deprivation) ${ }^{32}$ may impair the body's ability to maintain allostasis, producing wear and tear on bodily systems, compromised immunefunction, and enhanced general susceptibility ${ }^{11,32}$, and enhancing responsivity to environmental toxicants including air pollution. For example, some toxicologic evidence suggests permanent alteration in hypothalamic-pituitary-adrenal (H PA) function associated with chronic stress and lead exposures $^{33,34}$. However, some biological systems involved in maintaining allostasis may also beworn down by repeated exposureto physical toxicants, as particle exposures may influence H PA function ${ }^{35}$. Finally, some air pollutants and psychosocial stress may independently affect common physiologic processes such as oxidative stress ${ }^{36}$ or inflammatory cell [immunoglobulin E (IgE)] production $^{37,38}$.

M ore studies have explored air pollution effect modification by socioeconomic status (SES) than by stress. Given other evidence of greater stress-related illness and susceptibility among persons with lower SES ${ }^{39-41}$, heightened air pollution responses with lower SES may be mediated through stress-related pathways. The American Cancer Society (ACS) studies reported stronger effects of air pollution on respiratory, cardiovascular, and all-cause mortality among lower-SES persons $\mathrm{s}^{42}$, supported by other studies reporting stronger air pollution-health associations among less-educated adults's-45. Time-series studies have indicated that lower-SES persons display stronger associations between short-term air pollution exposures and health ${ }^{46-48}$, although not consistentIy ${ }^{49}$. These studies, however, have not explored specific components of SES that may be responsible for susceptibility effects, although stress has been proposed as a key component.

Several theoretical perspectives suggest that social, economic, and psychological disadvantage 
may cluster ${ }^{50-53}$. Fundamental causes theory, for example, describes social conditions (e.g., socioeconomic position) as determinants of resource access and psychological and behavioral experience, shaping disease risk ${ }^{54}$. Although applicable to combined social and physical exposures, these theories have not addressed methodologic issues (e.g., spatial correlation, confounding, measurement bias) or interpretation challenges arising in combining theory, methods, and data across disciplines. Likeair pollution, low SES and stressors (e.g., noise) may be elevated in urban settings along highways and industrial areas, and methods are needed to disentangle effects of clustered social and physical stressors and to investigate potential synergies. O ne model ${ }^{2}$ captures our key constructs of interest: a) varied stressors at the individual and community level contribute to individual chronic stress; b) chronic individual stress is embodied as allostatic load, or physiologic wear and tear, influencing individual susceptibility; and c) stress-borne physiologic susceptibility may shape response to environmental exposures, including internal dose, resiliency, likelihood of developing a given illness, and ability to recover from it.

Likeother models combining social and physical exposures ${ }^{1,3,55}$, the M orello-Frosch model acknowledges that some community-level stressors arealso physical hazards (e.g., poor housing quality), complicating distinctions between effects of psychosocial and physical factors. This model frames our discussion, although it is outside the scope of our review to describethe myriad possiblesocial, political, and economic forces that contribute to individual stress. Instead, we focus our attention on individual-level stress and pollution susceptibility, given that higher-level stressors need be individually embodied to modify pollution effects through stress-specific pathways.

Webuild on conceptual models of social-environmental interaction by describing key methodologic and conceptual issuesthat arise when merging data and methods from across environmental and social sciencetraditions. Wehopeto foster more integrative approaches toward understanding combined health effects of social and physical environ-mental exposures. We attempt to synthesizethe literature to date on the following:

. Effects of stress on respiratory health and susceptibility

- Epidemiologic and toxicologic evidence of synergistic effects of stress and pollution

. Pathways through which stress may influencepollution susceptibility
- Methodologic challenges in merging data and methods from environmental and social sciences.

We aim to provide atemplate for research-ers aiming to rigorously consider combined effects on health across disciplines. We hope to support the growing literature targeted at disentangling effects of spatially clustered social and environmental exposures and exploring potential synergies among these exposures.

Physiologic effects of psychological stress on respiratory health and susceptibility

A long history of research links psychological stress and respiratory health. In Treatise on Asthma, M aimonides (1135-1204) described the illness- "Whereas treatment of asthma is important, treatment of a patient as a whole is more important. For asthma the physician must be a doctor in every sense"- and described the importance of clean air and its interplay with emotions and hormones ${ }^{56}$. In the 1930s, H ans Selye recognized links between chronic stress in laboratory rats and nonspecific susceptibility to respiratory distress and death ${ }^{57}$. M ore recently, chronic stress has been linked to asthma symptoms in cross-sectional studies ${ }^{58}$, and prospectivestudies link caregiver stress to infant wheez ${ }^{59}$. Among asthmatic adolescents, SES has been associated with stress-linked immune mediators [interleukin (IL)-5, interferon- $\gamma$ ], an association mediated by stress and control beliefs ${ }^{60}$. Acute stressors (e.g., violent events) may trigger asthma episode ${ }^{61,62}$, and older individuals with greater psychological distress and anger display faster lung function declineover time ${ }^{63}$.

Distinctions between acute (short-term, generally lasting days to weeks) and chronic (longer-term, lasting weeks to years) stress is not always clear. Some severe acute stressors (e.g., sexual violence, or combat) can produce chronic stress effects (i.e., post-traumatic stress disorder). Assessing stress chronicity is important, however, as acute and chronic stress can produce substantively different physiologic sequelae, and the predominance of acute versus chronic stress experience in a given period may shape observed relationships between stress and susceptibility. Acute stress is linked to sympathetic innervation, including increased ventilation and bronchodilation, plausibly masking some short-term effects air pollution effects (e.g., acute irritation, broncho-constriction). Conversely, chronic stress 
can produce wear and tear on bodily systems, weaken immunefunction, and increase pollution susceptibility. Because of thesevery different physiologic sequelae, careful consideration of stress chronicity and of the relativechronicities of stress and pollution exposures is critical in accurately characterizing their interplay and in interpreting interactions.

Acutestress, sympatheticregulation, and the fight-or-flight response

Sympathetic nervous system activation under acute stress produces the immediate, short-term fight-or-flight response. N eural synapses produce catecholamines (e.g., epinephrine and norepinephrine or adrenaline and noradrenaline), and catabolic functioning breaks down metabolites for physical activity and energy expenditure. Glucocorticoids are produced, including cortisol, increasing heart rate, ventilation, myocardial contraction force, arterial vasodilation to working muscles, vaso-constriction to nonworking muscles, and dilating pupils and bronchi. Under acutestress, parasympathetic nervous system-regulated activities subside (e.g., salivary and intestinal secretions for digestion and nutrient absorption, growth and repair). Frequent sympathetic nervous system dominance under repeated acute stress may interfere with growth and repair, especially important for children's development, and suggests one pathway through which childhood stress may shapelifelong health and susceptibility.

Chronic stress, immune function, and inflammatory response

Chronic stress may be characterized by recurrent acutestress or an inability to moderate acute stress responses ${ }^{11}$. Building on $\mathrm{H}$ ans Selye's model of nonspecific susceptibility and allostatic load models of cumulative wear and tear, attention is increasingly being directed toward identifying biological mediators linking chronic stress to immune and endocrine function ${ }^{64,65}$.

Chronic stress and associated negative emotional states (e.g., depression, anxiety, anger) may mediateimmuneand endocrine processes ${ }^{66}$, with associations so consistent that some researchers have proposed reconceptualizing depression as dysfunction in HPA-axis regulation and stress response $^{67}$. Endocrine responses to chronic stress includedysregulation in production of catecholamines (epinephrine, norepinephrine), adrenocorticotropin, cortisol, growth hormone, and prolactin. Cytokines, particularly IL 6, stimulatecorticotrophin-releasing hormone and H PA-axis activity, increasing plasma adrenocorticotropin hormone and cortisol ${ }^{68-71}$. Frequent activation of the glucocorti-coid receptor by cortisol can lead to blunted glucocorticoid response ${ }^{64}$, increased nuclear factor- $\mathrm{\kappa B}$ signaling ${ }^{72}$, and dysregulated catecholamine production ${ }^{73}$.

Immune-linked inflammatory response may infleunceasthma and related airway disease. Asthma-linked parameters responsiveto stressinclude $\lg \mathrm{E}^{74}$ and cytokine production ${ }^{60}$ and respiratory inflammation ${ }^{75}$. Early life chronic stress may alter T-helper (Th)1-Th2 immune cell balance ${ }^{75}$, which is linked with childhood asthma, allergy, and inflammatory responses ${ }^{40}$.

\section{Impacts on common physiologic systems}

Growing evidence suggests complex dosedependent interactions among multiple pollutants ${ }^{76}$, mediated through the same mechanistic pathway, or some pollutants may potentiate effects of others. Similarly, stress may potentiate pollution health effects through immune and inflammatory processes, or stress and pollution may affect common physiologic systems. Both early childhood environmental exposures and stressrelated catecholamines affect Th1-Th2 balance ${ }^{75}$. Psychological stress ${ }^{77}$, polycyclic aromatic hydrocarbons, cigarette smoke ${ }^{78}$, and ozone ${ }^{36}$ affect oxidative stress, which is linked to asthma and COPD ${ }^{79}$. Both stress and diesel exhaust particles are associated with elevated cytokines (e.g., IL-2, IL-6, and local IgE in nasal mucosa) $)^{37,38}$. Some evidence suggests that stress may alter permeability of bodily membranes to chemical exposures, such that stress may alter systemic transport and chemical uptake into organs including thebrain ${ }^{80}$, facilitating combined and synergistic effects of stressors and pollution on many bodily systems.

\section{Key issues to be addressed as this work progresses}

Careful attention to stress measurement

For environmental researchers, social epidemiologic theory and methods for stress measurement may be unfamiliar, but accurately under- 
standing and applying these principles is necessary to produce meaningful analyses of interactions among stressors and pollution exposures. Careful attention to stress processes and distinction among the major components is needed to accurately capture and interpret stress effects on susceptibility. M oreover, because perceived stress is highly variable over time, it is important that measured stress periods are temporally appropriate to the pollution exposures and outcomes under study. The stress process is often described in three phases: a) the stressor (i.e., any event, condition, or external stimuli posing a physical or psychological challenge), b) stress appraisal (i.e., how one experiences, perceives, or interprets the event), and c) stress response (e.g., psychological and physiologic sequelae).

These phases are interdependent. A stressor appraised as benign or beneficial, rather than threatening, generally produces no stress response. Highly thorough stress assessments would measure each stage, which is rarely feasible. M ost studies focus on a single, chronic stressor (e.g., caregiver burden) or one unlikely to be positively appraised (e.g., exposure to violence, natural disaster). Newer measures emphasizelater stages of the stress process. Because of inconsistent findings with stressor measures (e.g., life event scal es assessing major life changes) ${ }^{81}$, more researchers today use perceived stress measures, which capture response to multiple stressors ${ }^{28,82}$. Recent evidence indicates, however, that subjective stress may poorly predict immune change ${ }^{65}$; thus, another approach emphasizes negative affect (e.g., anxiety, depression) as a cumulative indicator of mental distress and psychosocial stress. N egative affect may serve as a common final pathway for multiple psychological stressors, possibly providing a more stable indicator of cumulative stress and susceptibility ${ }^{39,83}$.

Other approaches include using biomarkershormones or immune markers associated with physiological stress responses, including glucocorticoids or cytokines ${ }^{64}$. Although many physiologic systems areinfluenced by acuteand chronic stress, there is relatively little consensus on optimal biomarkers to capture physiologic changes with acute or chronic stress. Formerly, corticosteroids (e.g., cortisol) in blood or saliva were emphasized as markers of H PA-axis activity, although stress-related H PA function changes lead to cortisol dysregulation (via glucorticoid resistance and H PA regulation), not simply increased cortisol production. Thus, cortisol can be difficult to interpret and better indicates acuterather than chronic stress. Recent research emphasizes indicators of glucocorticoid resistance and neuroendocrine signaling ${ }^{72}$. Other evidence suggests that $\mathrm{C}$-reactive protein ( $\mathrm{M}$ iller $\mathrm{G}$, personal communication) and tumor necrosis factor- $\alpha$ (unpublished data by Clougherty JE, Rossi CA, Lawrence J, Long $M$, Diaz E, Koutrakis $P$ et al.) may capture chronic stress in rats. Although no single biomarker is appropriate for all applications ${ }^{84}$, suites of physiologic parameters havebeen developed to represent allostatic load in humans, including indicators of cardiovascular function, metabolism, cholesterol, glucose metabolism, H PA-axisfunction, and sympathetic nervous system activity ${ }^{39,85}$. Several studies document chronic stress effects on cardiovascular risk indicators (abdominal obesity, el evated serum triglycerides, low high-density lipoprotein cholesterol, glucose intolerance, elevated blood pressure) ${ }^{86}$, known collectively as metabolic syndrome, and may providea method for capturing cumulativestress effects on cardiovascular and systemic function.

Relative temporality in stress

and pollution exposures

Generally, stressors must precede or be contemporaneous with pollution exposures to plausibly modify their effects. The actual periods of stress and pollution exposures, their overlap, and temporal relation to health outcomes, deserve careful attention, becausetemporal exposuremisclassification may nullify or even reverse the directionality of observed interactions. For example, if stress exposure occurs after or very latein a pollution exposureinterval, interpreting observed interactions is problematic. If perceived stress is stable over time, the report will accurately reflect stress during the hypothesized period of susceptibility. If perceived stress varies over the period, however, and respondents compare current stress to prior experiences, then individuals reporting high stress likely experienced relatively lower stress previously, during the pollution exposure period. Such temporal misclassification may significantly confound results, and researchers should ensure that stress and pollution measurement periods support a plausible physiologic interaction in relation to the health outcome of interest.

Spatial correlations

among social and physical exposures

Both social and physical exposures vary across communities, and lower-income and minority 
communities may be disproportionately exposed to both $2,51,87$. Strong spatial covariance among stress, SES, and pollution has confounded geographic information systems (GIS)-based air pollution epidemiology, and spatial epidemiologists are challenged to differentiate health effects of traffic-related pollution from those of spatially correlated noise, stress, or poverty. Evidence suggests that roadway noise, a spatial stressor correlated with pollution, increases heart rate among adults and children ${ }^{88,89}$, and living in hightraffic areas predicts higher stress, lower self-reported health, and depressive symptoms ${ }^{90}$, effects distinct from those of pollution per se.

Because of spatial autocorrelation and possible confounding, accurate fine-scale exposure assessment for both stress and pollution is critical. GIS-based exposure models, now common in environmental epidemiology, should be validated to the spatial extent of the cohort examined, and spatial patterns in stressors and pollution, at multiple levels, should be carefully considered to avoid spatial misclassification and confounding. Social-physical correlations may vary by region or context, and the appropriate geographic scale of analysis may vary as well. The 1995-1997 H ealth Survey for England found that in urban areas, lower-SES households experienced worse air quality, although the opposite was true in rural regions. Air quality and SES independently predicted lung function in both settings, with greater pollution susceptibility among lower-SES men, but not women ${ }^{10}$.

Although some neighborhoods may experience higher average levels of pollution and stressors (variation across neighborhoods), one should not assume that individuals or residences within these neighborhoods are relatively more exposed to both (variation within neighborhoods). Individuals living closer to highwayslikely have higher pollution exposures than do other community residents but are not necessarily more exposed to violence or family stress. Similarly,U.S. census tracts, selected to be relatively homogeneous for key sociodemographic indicators, may be a meaningful unit of analysis for some social and economic factors ${ }^{91}$. All persons within a census tract, however, do not have similar trafficrelated pollution exposures, which vary dramatically within $50-200 \mathrm{~m}$ of major roadways ${ }^{92}$.
Nonlinear, threshold, and saturation effects

Thereis evidencelinking stress and air pollution, separately, to asthma onset and exacerbation. Because both exposures independently influence respiratory health, we might expect that with especially high levels of either exposure, exacerbations likely occur, regardless of the second exposure. Effectively, very high exposures may overpower any potential interaction effects.

Potential saturation effects call for careful attention to the exposure range observed in any study, relative to normal exposure levels, to inform whether interactions should be expected and how to interpret observed interactions. For example, our group reported that asthmatic children of families reporting higher fear of violence showed less symptom improvement with allergen-reducing indoor environmental interventions $^{93}$. Counter to initial hypotheses, this result suggested saturation effects in our very high-exposure public housing cohort. Either fear of violence or allergen exposures may have been high enough to independently induce or maintain symptoms.

\section{The need for toxicologic research}

Because of strong potential confounding between stressors and pollution, epidemiologic methods alone are unlikely to fully differentiate their effects or resolve spatial confounding. Additionally, chronic air pollution exposure may contribute to HPA axis stimulation and stress process$\mathrm{es}^{35}$. Thus, experimental studies using well-developed animal models of social stress (e.g., monkeys, rats) are needed to delineate these effects. Toxicologic data can improvecausal inferenceand interpretability by randomizing exposures, controlling their temporality and intensity, and, importantly, can help elucidate physiologic mechanisms for stress-pollution interactions.

Several authors have investigated stress as a modifier of neurologic effects of lead in animal models. Cory-Slechta et al. ${ }^{94}$ examined separate and combined effects of restraint stress and lead in pregnant dams on corticosterone, neurotransmitter levels, and behavioral learning. They found significant interactions, generally more prominent in female offspring, and noted that lead al one influenced corticosterone, suggesting that lead may influence later-life susceptibility ${ }^{33,34}$. They observed strongly altered H PA axisfunction with both lead and stress, separately and in combina- 
tion, providing a model for better understanding the etiology of conditions linked to both exposures and potentially mediated through HPA function, including obesity, hypertension, diabetes, anxiety, schizophrenia, and depression ${ }^{95}$.

We recently compared short-term respiratory response to concentrated fine particulate air pollution (CAPs) among chronically stressed and unstressed rats. U sing the social dominance paradigm, a rat model of social stress ${ }^{96,97}$, we introduced maletest rats individually into the cage of an older, larger male, over an 8-week period, to establish chronic stress conditions. Test animals were exposed to controlled CAPs for $5 \mathrm{hr}$ on days after stress exposures. Across four exposure groups [stress/CAPs; stress/filtered air (FA); nonstress/CAPs; nonstress/FA], animals exposed to both stress and CAPs displayed elevated Creactive protein and altered respiratory function relative to other groups, with higher frequencies and briefer pauses after inspiration and expiration, suggesting a shallower, more rapid breathing pattern ${ }^{98}$.

Experimental studies involving humans

Experimental studies have identified physiologic parameters associated with stressors in humans (exam stress, public speaking). Although these studies can examine only short-term, relatively benign stressors, they do allow for controlled, randomized stressor exposures that are not feasible in the community setting. Fiedler et al..$^{99}$ examined combined effects of stressors (public speaking, math challenge) and oxidation by-products of indoor volatile organic carbons and ozone, prevalent in office settings, on cortisol, respiratory function, and symptoms (anxiety, eye/nose irritation, respiratory symptoms) at multiple time points. They found that stress pre dicted anxiety symptoms and cortisol, outweighing any potential interaction with pollution ${ }^{99}$. Such experimental studies cannot mimic the lifelong stress and pollution exposures associated with low SES but help to elucidate some mechanisms for stress-related susceptibility and, importantly, allow for the separation of persistently correlated exposures, otherwise difficult to delineate.

Pollution and pollution sources as psycho-social stressors

Health geographers influenced by the environmental justice movement have long understood that neighborhood pollution sources, in- cluding highways, power plants, and smokestacks, can send strong messages to residents about the value of their health and well-being to the larger society ${ }^{7}$. Indeed, the study of air pollution effects on health has historically considered its psychological effects ${ }^{100,101}$, including psychosocial impacts of perceived exposure ${ }^{102}$ on vigilance ${ }^{103,104}$, test performance ${ }^{105}$, irritation ${ }^{106}$, aggression ${ }^{102}$, behavior ${ }^{107}$, neurologic effects ${ }^{105}$, and vision impairment ${ }^{108}$. M ore recent evidenceindicates that air quality below regulatory guidelines can be detected by residents, with negativehealth consequences ${ }^{109}$, although perceived air quality can also be influenced by disease status ${ }^{110}$. Indeed, it can be difficult to distinguish health effects produced by the physical aspects of air pollution from its psychosocial health effects in communities near toxic sites ${ }^{111,112}$, to separate both pollution-derived effects from those of other spatially correlated stressors, or to establish directionality. To better elucidate this complex synergy among exposure pathways, environmental exposure assessment and risk management may ultimately consider both tangible physical and psychosocial effects of pollution to fully understand the mechanisms linking air pollution, stress, and susceptibility.

\section{Additional questions to be explored}

$M$ any questions about stress-related pollution susceptibility remain. We raise several here, describing each only briefly, and hope these issues will be explored in detail in coming years.

To which pollutants and health out-comes is stress-related susceptibility relevant?

A few studies demonstrate significant stressrelated modification in air pollution effects on respiratory health, particularly asthma onset ${ }^{29}$ and exacerbation ${ }^{30,93}$. Stress may also modify relationships between bone lead and cardiovascular out-comes (e.g., hypertension) ${ }^{31}$ and, in the same data set, heart ratevariability (unpublished data by CloughertyJE, Peters L, Schwartz J, Kubzansky L). A growing toxicology literature demonstrates stress-related susceptibilities to neurocognitive effects of lead and polychlorinated biphenyls, including neurologic damage and hippocampal function ${ }^{94}$. These vastly different exposures and outcomes demonstrating stresspollutant interactions and the many physiologic systems affected by stress (e.g., sympathetic reg- 
ulation, immune function, glucocorticoid production) suggest potential stress-related modifications in a wide range of pollutant exposures on health outcomes.

Are these interactions different in illness onset than in exacerbation?

For preexisting illness, many factors may modify stress effects on illness severity and chronicity, including current medical treatment and comorbidities. The progression of preexisting illness, if influenced by stress, may also change the relevant temporalities, as later stress could plausibly modify recovery from environmentally derived illness. Thus, stress-pollution interactions may beeven more complicated for existing illness, and careful attention to temporality and confounding (e.g., by medical treatment) is even more important. Some evidence suggests that stress may modify pollution effects in exacerbating preexisting asthma $\mathrm{a}^{30,93}$, although both studies produced associations opposite to hypotheses (stronger pollution effects with lower stress). M ore generally, attention to distinguishing processes related to illness onset from illness progression or exacerbation will becritical in assessing whether interactions are robust or should be expected in healthy populations.

Are there critical periods for stress and pollution exposures across the life course?

Different diseases are relevant at different life stages. Asthma is among the most prevalent chronic illnesses of childhood, whereas cardiovascular illness generally afflicts older persons. Becausethelife-course distribution of illness varies considerably, relationships among stress, susceptibility, and illness likely also vary with age. Although stress can be toxic at any age, there may be critical periods, such as during early immune development, when it is particularly influential in shaping future susceptibility and disease risk ${ }^{51}$.

Parental stress has been used to examinestress exposures in young children, and research supports inverse associations for both mother's SES and depressivestates on children's stress hormone levels $s^{113}$. Prospectivestudies havelinked care-giver stress to infant wheeze ${ }^{59}$, and maternal stress during pregnancy may influence immune function and health in neonates ${ }^{6}$. M aternal air pollution exposures associated with low birth weight ${ }^{114}$ may increase later childhood respiratory disease risk. Stress exposures during development may produce broad biological and psychological vulnerabilities, affecting neuroendocrine, immune, metabolic, and growth processes ${ }^{115}$. Although not entirely immutable, these effects may have permanent and compounding consequences, especially if not addressed early ${ }^{116,117 .}$

What are the roles of gender/sex and race/ ethnicity in shaping stress-related susceptibility to pollution?

It is beyond the scope of this review to describe the myriad societal-level sources of stress. However, ongoing research in this area will be informed by the growing literatures on racism as a prevalent stressor, and on sex and gender differences in psychological and physiologic responses to stress and susceptibility.

Racial and ethnic minority groupsin the United States are often differentially exposed to psychosocial stressors and physical contaminants in their homes, neighborhoods, and workplaces? The environmental justice movement has drawn attention to disproportionatepollution exposures in minority and low-income communities ${ }^{18}$, but only recently has attention been directed to combined pollution exposures and greater susceptibility in these communities $2,29,51,119$. Experiences of racism as a stressor have been associated with negative physical and emotional health effects ${ }^{120-}$ 125 modified by coping practices and social support ${ }^{123}$. Experiences of racial discrimination predicted poorer birth outcomes among women with Arabic names in California after 11 September $2001^{126}$. There is also evidence of poorer health, including mortality, for U.S. persons than for foreign-born persons of the sameethnicity, especially $\mathrm{H}$ ispanics ${ }^{127}$. Effects of race and racism are not fully mediated through social class ${ }^{123}$ and are not generally attributable to genetic variation ${ }^{128}$. Racerelated stressors may contribute to "weathering" or physiologic wear and tear ${ }^{129-131}$. H ypertension onset, for example, may be four to seven times higher among low-SES than among high-SESAfrican-American men ${ }^{132}$. African Americans also have higher rates of cardiovascular illness ${ }^{133}$ and low birth weight ${ }^{134}$ relative to Caucasians with comparable education.

Sex and gender differences in stress and susceptibility may besignificant. Thedistinction between gender (socially influenced behaviors) and sex (biology, including hormonal composition, sex organs, and anthropometric measures) is comparable with that between exposure and susceptibility. Sex differences have been observed 
in air pollution-health associations. After early childhood, more studies report greater risks among women and girls $\mathrm{s}^{135-138}$, possibly explained, in part, by biological sex differences in lung capacity, hormonal status, inflammation, or airway particledeposition ${ }^{139,140}$. Gendered social and behavioral patterns also matter. Sex stratification in theworkforceand work-related exposures are well documented ${ }^{141,142}$. Among children, play activities may influenceventilation rate, creating exposure differences between boys and girls ${ }^{143}$. Common pollution exposures metrics may be differently accurate by gender; residential exposures may better capture exposures for stay-athome parents (usually mothers) than for working adults 144,145 . Physiologic stress responses differ by sex ${ }^{146,147}$, as does observed effect modification by SES ${ }^{10}$, such that gendered stress assessment may be needed to fully understand stresslinked effect modification for air pollution.

To what extent are the effects of SES attributable to stress?

Asdescribed, there is growing evidence of SES effect modification in the air pollution-disease relationship. ACS studies reported stronger health effects of air pollution among less-educated adults ${ }^{42}$, and time-series studies report the same ${ }^{46-}$ 48,148 , although these air pollution studies have not identified causal components of SES shaping suscepti bility. Likeair pollution, SES is a complex exposure mix accumulated over the life course, potentially including poorer-quality education; nutrition; housing; health care; health behaviors; pollution exposures in the home, community, and workplace; perceived social position; and other stressors. Indeed, newer variants of the allostatic load model incorporate primary (e.g., perceived stress, psychological response) and secondary (e.g., smoking, sleep, dietary behaviors) manifestations of stress ${ }^{32}$. Growing evidencelinks low SES to perceived stress and distress ${ }^{40,149}$ and to biological markers of stress-related susceptibility ${ }^{87}$. Some of these studies used allostatic load models to link SES to distress and markers of disease risk (e.g., metabolic dysregulation) ${ }^{39}$. Other studies link allostatic load parameters to morbidity and mortality, suggesting that allostatic load may mediaterelationships between SES and mortality, after accounting for demographic characteristics and physician-diagnosed illness ${ }^{41}$.

Among children, low SES may bea marker of early exposure to adversity. Recent studies link low childhood SES to epigenetic changes in mes- senger ribonucleic acid (mRNA) for the glucocorticoid receptor and toll-like receptor 4, indicative of proinflammatory profiles associated with asthma and allergic illness ${ }^{40}$. Low-SES children 6-10 years of age have shown higher basal cortisol levels than higher-SES children ${ }^{87}$. Children of parents reporting higher stress display physiologic hyperrespon-siveness, and low-incomechildren of depressed mothers show sex-specific physiologic responses: elevated cortisol in girls, HPA axis hypoactivity in boys ${ }^{150}$. Children of depressed mothers can display altered adrenocorticotropic hormone and corticotropin-releasing hormone production into young adulthood ${ }^{151}$. Evidencesuggesting that stress is a key media-tor for SES effects on health is not universally endorsed, and associations between SES and stressrelated biological changes are not always positive ${ }^{152}$. Authors have argued that psychosocial factors are inextricably bound to material factors in developed countries; therefore, the accumulated evidence does not unequivocally demonstrate an independent pathway by which psychosocial stress may link SES to physical health ${ }^{153}$. Other aspects of SES (e.g., nutrition, health care) may also influence pollution susceptibility, and methodsareneeded to determinetheir effects. We believe that the evidence to date is broadly suggestive of a link between SES and physiologic susceptibility, a significant portion of which may beexplained by life stress. Continued research in this area is valuable, especially as it improves our understanding of the pathways through which physical exposures, including pollution, may differently impinge on the health of vulnerable populations.

\section{Conclusions}

There is tremendous potential, although much work still to be done, in understanding combined effects of social and physical environmental exposures. These topics are exceedingly complicated. Accurately characterizing both social and physical exposures is a significant challenge that must be performed carefully, especially in light of potential confounding across the exposures of interest, before analyzing and interpreting interactions.

The issues we have highlighted here - temporal relationships between stressors and pollution; nonlinearity and saturation effects; spatial colinearity across exposures; age related susceptibility and critical periods; and distinctions between processes related to illness etiology and 


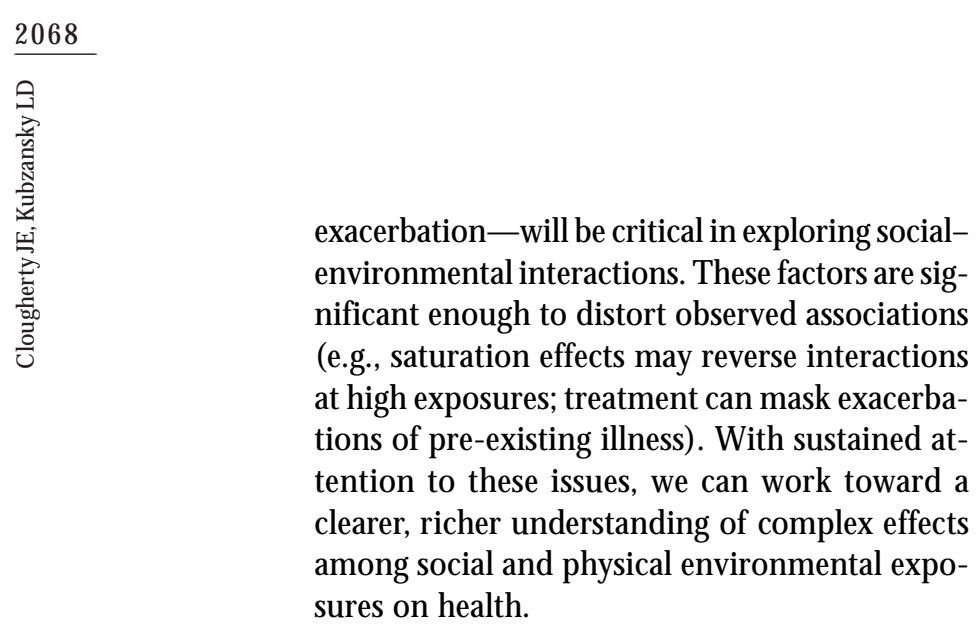

Acknowledgements

We are very grateful to B. M cEwen for his helpful suggestions on this manuscript.

\section{References}

1. Gee G, Payne-Sturges D. Environmental health disparities: a framework for integrating psychosocial and environmen-tal concepts. Environ Health Perspect 2004; 112:1645-1653.

2. Morello-Frosch R, Shenassa ED. The environmental "risk-scape" and social inequality: implications for explaining maternal and child disparities. Environ Health Perspect 2006; 114:1150-1153.

3. O'N eill M, Jerrett M, Kawachi I, Levy J, Cohen A, Gouveia N, Wilkinson P, Fletcher T, Cifuentes $L$, Schwartz J; Workshop on Air Pollution and Socioeconomic Conditions. Health, wealth, and air pollution: advancing the-ory and method. Environ Health Perspect 2003; 111:1861-1870.

4. O'N eill M, M CM ichael A, Schwartz J, Wartenberg D. Poverty, environment, and health: the role of environ-mental epidemiology and environmental epidemiologists. Epidemiology 2007; 18(6):664-668.

5. O'Neill MS, Veves A, Sarnat JA, Zanobetti A, Gold $D R$, Economides PA, Horton ES, Schwartz J. Air pollution and inflamma-tion in type 2 diabetes: a mechanism for susceptibility. O ccup Environ Med 2007; 64(3):373-379.

6. Weiss B, Bellinger DC. Social ecology of children's vul-nerability to environmental pollutants. Environ Health Perspect 2006; 114:1479-1485.

7. Bullard R. Dumping in Dixie: Race, Class, and Environmental Quality. Boulder, CO: Westview Press; 1990.

8. Graves P. The robustness of hedonic price estimation: urban air quality. Land Econ 1988; 64:220-233.

9. Schauer JJ, Lough GC, Schafer M M, Christensen WF, Arndt M F, DeM inter JT, Park JS. Characterization of metals emitted from motor vehicles. Res Rep Health Eff Inst 2006; 133:1-7.

10. Wheeler B, Ben-Shlomo Y. Environmental equity, air quality, socioeconomic status, and respiratory health: a linkage analysis of routine data from the $\mathrm{H}$ ealth Survey for England. J Epidemiol Community $H$ ealth 2005; 59:948-954. 
11. M CEwen BS, Seeman TE. Protective and damaging effects of mediators of stress. Elaborating and testing the concepts of allostasis and allostatic load. Ann NY Acad Sci 1999; 896:30-47.

12. Lipfert FW. Air pollution and poverty: Does the sword cut both ways? J Environ Community Health 2004; 58:3-5.

13. U.S. Environmental Protection Agency. Integrated Science Assessment for Oxides of Nitrogen- $\mathrm{H}$ ealth Criteria. Research Triangle Park, NC: National Center for Environmental Assessment, Office of Research and Development; 2008.

14. Hiltermann T, Bruijne CD, Stolk J, Zwinderman A, Spieksma F, Roemer W, Steerenberg PA, Fischer $\mathrm{PH}$, van Bree L, H iemstra PS. Effects of photochemical air pol-lution and allergen exposure on upper respiratory tract inflammation in asthmatics. Am J Respir Crit Care M ed 1997; 156(6):1765-1772.

15. Schikowski T, Sugiri D, Ranft U, Gehring U, Heinrich J, Wichmann E, Krämer U. Long-term air pollution exposure and living close to busy roads are associated with COPD in women. Respir Res 2005; 6(1):152.

16. Vineis $P$, Hoek $G$, Krzyzanowski $M$, Vigna-Taglianti $F$, Veglia F, Airoldi L, Overvad K, Raaschou-Nielsen $O$, Clavel-Chapelon $F$, Linseisen J, Boeing $H$, Trichopoulou A, Palli D, Krogh V, Tumino R, Panico $S$, Bueno-De-M esquita $H B$, Peeters PH, Lund $E E$, Agudo $A, M$ artinez $C$, Dorronsoro $M$, Barricarte A, Cirera L, Quiros JR, Berglund G, Manjer J Forsberg B, Day NE, Key TJ, Kaaks R, Saracci R, Riboli E. Lung cancers attributable to environmental tobacco smoke and air pollution in non-smokers in different European countries: a prospective study. Environ Health 2007; 15:6:7.

17. Dockery D. An association between air pollution and mor-tality in six U.S. cities. N Engl J M ed 1993; 329:1753-1759.
18. Pope C III, Thun M, Namboordiri M, Dockery D, Evans J, Speizer F. Particulate air pollution as a predictor of mortality in a prospective study of U.S. adults. Am J Respir Crit Care Med 1995; 151(3):669-674.

19. Jang $A$, Yeum $C$, Son M. Epidemiologic evidence of a relationship between airway hyperresponsiveness and exposure to polluted air. Allergy 2003; 58(7):585588.

20. Ryan $P$, LeM asters $G$, Biswas $P$, Levin $L$, Hu S, Lindsey $M$, Bernstein DI, Lockey J, Villareal M, Khurana Hershey GK, Grinshpun SA. A comparison of proximity and land use regression traffic exposure models and wheezing in infants. Environ $\mathrm{H}$ ealth Perspect 2007; 115:278-284.

21. McConnell R, Berhane K, Yao L, Jerrett M, Lurmann F, Gilliand FD, Künzli N, Gauderman J, Avol E, Thomas D, Peters J. Traffic, susceptibility, and child-hood asthma. Environ $\mathrm{H}$ ealth Perspect 2006; 114:766-772.

22. Pekkanen J, Timonen K, Ruuskanen J, Reponen A, Mirmes A. Effects of ultrafine and fine particles in urban air on peak expiratory flow among children with asthmatic symp-toms. Environ Res 1997; 74:2433.

23. Lin S, Munsie $P$, H wang $S-A$, Fitzgerald E, Cayo MR. Childhood asthma hospitalization and residential exposure to state route traffic. Environ Res 2002; 88(A):73-81.

24. Moore K, Neugebauer R, Lurrmann F, Hall J, Brajer V, Alcorn S, Tager I. Ambient ozone concentrations cause increased hospitalizations for asthma in children: an 18-year study in Southern California. Environ Health Perspect 2008; 116:1063-1070.

25. Peters A. Particulate matter and heart disease: evidence from epidemiological studies. Toxicol Appl Pharmacol 2005; 207(2):477-482. 
26. Rückerl R, Ibald-Mulli $A$, Koenig W, Schneider $A$, Woelke G, Cyrys J, Heinrich J, M arder V, Frampton $M$, Wichmann HE, Peters A. Air pollution and markers of inflam-mation and coagulation in patients with coronary heart disease. Am J Respir Crit Care M ed 2006; 173(4):432-441.

27. Lanki T, de Hartog JJ, Heinrich J, Hoek G, Janssen NA, Peters A, Stölzel M, Timonen KL, Vallius M, Vanninen $E$, Pekkanen J. Can we identify sources of fine par-ticles responsible for exercise-induced ischemia on days with elevated air pollution? The ULTRA study. Environ Health Perspect 2006; 114:655-660.

28. Cohen S, Kessler RC, Underwood GL. M easuring Stress: A Guide for Health and Social Scientists. New York: Oxford University Press; 1995.

29. Clougherty JE, Levy JI, Kubzansky LD, Ryan PB, Suglia SF, Canner MJ, Wright RJ. Synergistic effects of traffic-related air pollution and exposure to violence on urban asthma etiology. Environ $\mathrm{H}$ ealth Perspect 2007; 115:1140-1146.

30. Chen E, Schreier H M C, Strunk R, Brauer M. Chronic traffic-related air pollution and stress interact to predict biological and clinical outcomes in asthma. Environ Health Perspect 2008; 116:970-975.

31. Peters JL, Kubzansky LD, M CN eely E, Schwartz J, Spiro A, Sparrow D, Wright RO, Nie H, Hu H. Stress as a potential modifier of the impact of lead levels on blood pressure: The Normative Aging Study. Environ Health Perspect 2007; 115:1154-1159.

32. M cEwen BS. Sleep deprivation as a neurobiologic and physiologic stressor: allostasis and allostatic load. M etabolism 2006; 55(10 suppl 2):S20-S23.

33. Virgolini $M B, C$ hen $K$, Weston $D D$, Bauter $M R$, Cory-Slechta DA. Interactions of chronic lead exposure and inter-mittent stress: consequences for brain catecholamine systems and associated behaviors and HPA axis function. Toxicol Sci 2005; 87(2):469-482.

34. Virgolini MB, Bauter MR, Weston DD, Cory-Slechta DA. Permanent alterations in stress responsivity in female offspring subjected to combined maternal lead exposure and/or stress. N eurotoxicology 2006; 27(1):11-21.

35. Sirivelu MP, M ohanKumar SM J, Wagner JG, Harkema JR, M ohanKumar PS. Activation of the stress axis and neurochemical alterations in specific brain areas by concentrated ambient particle exposure with concomitant aller-gic airway disease. Environ Health Perspect 2006; 114:870-874.

36. Fugisawa T. Role of oxygen radicals on bronchial asthma. Curr Drug Targets Inflamm Allergy 2005; 4(4):505-509.

37. Diaz-Sanchez D, Penichet-Garcia M, Saxon A. Diesel exhaust particles directly induce activated mast cells to degranulate and increase histamine levels and symptom severity. J Allergy Clin Immunol 2000; 106:1140-1146.

38. Nel A. The role of particulate pollutants in pulmonary inflammation and asthma: evidence for the involvement of organic chemicals and oxidative stress. Curr Opin Pulm Med 2001; 7:20-26.
39. Kubzansky LD, Kawachi I, Sparrow D. Socioeconomic status, hostility, and risk factor clustering in the Normative Aging Study: any help from the concept of allostatic load? Ann Behav Med 2000; 21(4):330-338.

40. Miller G, Chen E. Unfavorable socioeconomic conditions in early life presage expression of proinflammatory pheno-type in adolescence. Psychosom M ed 2007; 69(5):402-409.

41. Seeman TE, Crimmins EM, Huang $M-H$, Singer $B$, Bucur A, Gruenewald TL, Berkman KF, Reuben $D B$. Cumulative biological risk and socio-economic differences in mortality: MacArthur Studies of Successful Aging. Soc Sci M ed 2004. 58:1985-1997.

42. Krewski D, Burnett RT, Goldberg MS, Hoover K, Siemiatycki J, Jerrett $M$, Abrahamowicz $M$, White WH. Reanalysis of the Harvard Six Cities Study and the American Cancer Society Study of Particulate Air Pollution and Mortality. Cambridge, MA: Health Effects Institute; 2000.

43. Finkelstein $M$, Jerrett $M$, DeLuca P, Finkelstein $N$, Verma D, Chapman K, Sears M R. Relation between income, air pollution, and mortality: a cohort study. Can Med Assoc] 2003; 169(5):397-402.

44. Hoek G, Brunekreef B, Goldbohm S, Fischer P, van den Brandt P. Association between mortality and indica-tors of traffic-related air pollution in the N etherlands: a cohort study. Lancet 2002; 360:1203-1209.

45. Pope C III. Lung cancer, cardiopulmonary mortality, and long-term exposure to fine particulate air pollution. JAM A 2002; 287:1132-1141.

46. Jerrett $M$, Burnett $R$, Brook J, Kanaraglou $P$, Giovis C, Finkelstein J, Hutchison B. Do socioeconomic char-acteristics modify the short term association between air pollution and mortality? Evidence from a zonal time series in $\mathrm{H}$ amilton, Canada. J Epidemiol Community $\mathrm{H}$ ealth 2004; 58:31-40.

47. Lin $M$, Chen $Y$, Villeneuve $P$, Burnett $R$, Lemyre $L$, Hertzman C, McGrail KM, Krewski D. Gaseous air pollutants and asthma hospitaliza-tion of children with low household income in Vancouver, British Columbia, Canada. Am J Epidemiol 2004; 159(3):294-303.

48. $M$ artins $M$, Fatigati $F$, Vespoli $T$, Martins L, Pereira $L, M$ artins $M$, Saldiva PH, Braga AL. Influence of socioeconomic conditions on air pollution adverse health effects in elderly people: an analysis of six regions of São Paulo, Brazil. J Epidemiol Community Health 2004; 58:41-46.

49. Zanobetti A, Schwartz J. Race, gender, and social status as modifiers of the effects of PM 10 on mortality. J Occup Environ Med 2000; 42:469-474.

50. Adler N, Matthews K. Health psychology: why do some people get sick and some stay well? Annu Rev Psychol 1994; 45:229-259.

51. Evans GW, English K. The environment of poverty: multiple stressor exposure, psychophysiological stress, and socioemotional adjustment. Child Dev 2002; 73(4):1238-1248.

52. Link B, Phelan J. Evaluating the fundamental cause explanation for social disparities in health. In: Bird C, Conrad P, Freemont A, editors. Handbook of Medical Sociology. Upper Saddle River, NJ: Prentice-Hall; 2000. 
53. Shonkoff JP, Phillips DA. From Neurons to Neighborhoods: The Science of Early Childhood Development. Washington, D.C.: National Academy Press; 2000.

54. Link B, Phelan J. Social conditions as fundamental causes of disease. J Health Soc Behav 1995; (extra issue) :80-94.

55. deFur PL, Evans GW, Cohen Hubal EA, Kyle AD, Morello-Frosch RA, Williams DR. Vulnerability as a function of individual and group resources in cumulative risk assess-ment. Environ $\mathrm{H}$ ealth Perspect 2007; 115:817-824.

56. Muntner $S$, editor. The Medical Writings of M oses Maimonides: Treatise on Asthma. Philadelphia, PA: Lippincott; 1963.

57. Selye H. A syndrome produced by diverse nocuous agents. Nature 1936; 138:32.

58. Oh Y-M, Kim YS, Yoo SH, Kim SK, Kim DS. Association between stress and asthma symptoms: a population-based study. Respirology 2004; 9:363-368.

59. Wright RJ, Cohen S, Carey V, Weiss ST, Gold DR. Parental stress as a predictor of wheezing in infancy: a prospective birth-cohort study. Am J Respir Crit Care M ed 2002; 165:358-365.

60. Chen E, Fisher EB, Bacharier LB, Strunk RC. Socioeconomic status, stress, and immune markers in adolescents with asthma. Psychosom M ed 2003; 65(6):984-992.

61. Sandberg S, Paton J, Ahola S, McCann D, McGuinness $D$, Hillary $C R, O j a H$. The role of acute and chronic stress in asthma attacks in children. Lancet 2000; 356(9234):982-987.

62. Sandberg S, Jarvenpaa S, Pettinen A, Paton J, M CCann D. Asthma exacerbations in children immediately fol-lowing stressful life events: a Cox's hierarchical regres-sion. Thorax 2004; 59:1046-1051.

63. Kubzansky LD, Wright RJ, Cohen S, Weiss ST, Rosner $B$, Sparrow D. Breathing easy: a prospective study of optimism and pulmonary function in the Normative Aging Study. Ann Behav Med 2002; 24(4):345-353.

64. Miller GE, Cohen S, Ritchey AK. Chronic psychological stress and the regulation of pro-inflammatory cytokines: a glucocorticoid-resistance model. Health Psychol 2002; 21:531-541.

65. Segerstrom S, Miller G. Psychological stress and the human immune system: a meta-analytic study of 30 years of inquiry. Psychol Bulletin 2004; 130(4):601-630

66. Kiecolt-Glaser J, McGuire L, Robles T, Glaser R. Emotions, morbidity, and mortality: new perspectives from psycho-neuroimmunology. Annu Rev Psychol 2002; 53:83-107.

67. Sternberg E, Choursos G, Wilder R, Gold P. The stress response and the regulation of inflammatory disease. Ann Intern M ed 1992; 117:854-866.

68. Hellhammer DH, Buchtal J, Gutberlet I, Kirschbaum $\mathrm{C}$. Social hierarchy and adrenocortical reactivity in men. Psychoneuroendocrinology 1997; 22:643-650.
69. Kirschbaum C, Prussner JC, Stone AA, Federenko I, Gaab J, Lintz D, Schommer N, Hellhammer DH. Persistent high cortisol responses to repeated psychological stress in a subordinate population of healthy men. Psychosom M ed 1995; 57:468-474.

70. Ockenfels M C, Porter L, Smyth J, Kirschbaum C, H ellhammer DH. Effect of chronic stress associated with unemployment on salivary cortisol levels, diurnal rhythm, and acute stress reactivity. Psychosom M ed 1995; 57:460-467.

71. Seeman TE, Singer B, Rowe JW, Horwitz RI, M CEwen BS. Price of adaptation: allostatic load and its health conse-quences. Arch Intern Med 1997; 157:2259-2268.

72. Miller GE, Chen E, Sze E, Marin T, Arevalo JMG, Doll R, Ma R, Cole SW. A functional genomic fingerprint of chronic stress in humans: blunted glucocorticoid and increased NF-kappaB signaling. Biol Psychiatry 2008; 64:266-272.

73. Glaser R, Kiecolt-Glaser JK. Stress-induced immune dysfunction: implications for health. $\mathrm{N}$ at Immunol 2005; 5:243-251.

74. Wright RJ, Finn P, Contreras JP, Cohen S, Wright RO, Staudenmayer J, Staudenmayer J, Wand M, Perkins D, Weiss ST, Gold DR. Chronic caregiver stress and IgE expression, allergen-induced proliferation, and cytokine profiles in a birth cohort predisposed to atopy. J Allergy Clin Immunol 2004; 113:1051-1057.

75. Umetsu DT, Mclntire JJ, Akbari O, Macaubas C, DeKruyff RH. Asthma: an epidemic of dysregulated immunity. Nat Immunol 2002; 3(8):715-720.

76. M auderly JL, Samet J. Is there evidence for synergy among air pollutants in causing health effects? Environ $\mathrm{H}$ ealth Perspect 2009; 117:1-6.

77. Epel E, Blackburn E, Lin J, Dhabhar F, Adler N, Morrow J, Cawthon RM. Accelerated telomere shortening in response to life stress. Proc N atl Acad Sci USA 2004; 101(49):17312-17315.

78. Adcock IM, Ito K. Glucocorticoid pathways in chronic obstructive pulmonary disease therapy. Proc Am Thorac Soc 2005; 2(4):313-319.

79. Rahman I, MacN ee W. Oxidative stress and regulation of glutathione in lung inflammation. Eur Respir J 2000; 16:534-554.

80. Sinton CM, Fitch TE, Petty F, Haley RW. Stressful manipulations that elevate corticosterone reduce blood-brain barrier permeability to pyridostigmine in the rat. Toxicol Appl Pharmacol 2000; 165:99-105.

81. Dohrenwend BP, Raphael KG, Schwartz S, Stueve A, Skodol A. The structured event probe and narrative rating method for measuring stressful life events. In: Goldberger L, Breznitz S, editors. Handbook of Stress. New York: Free Press; 1993. p. 174-199.

82. Cohen $\mathrm{S}$, Kamarack T, Mermelstein R. A global measure of perceived stress. J H ealth Soc Behav 1983; 24(4):385-396.

83. Seeman $T E$, Singer BH, Ryff CD, Dienberg Love G, Levy-Storms L. Social relationships, gender, and allostatic load across two age cohorts. Psychosom M ed 2002; 64:395-406. 
84. Brunner E. Biology and health inequality. PLOS Biol 2007; 5(11):2449-2452.

85. Seeman TE, Singer B. Psychosocial factors and the development of allostatic load. Psychosom M ed 2002; 64:395-406.

86. Brunner EJ, Marmot M G, N anchahal K, Shipley M, Stansfeld SA. Social inequality in coronary risk: central obesity and the metabolic syndrome. Evidence from the Whitehall II study. Diabetologia 1997; 30:1341-1349.

87. Lupien SJ, King S, M eaney MJ, M cEwen BS. Can poverty get under your skin? Basal cortisol levels and cognitive function in children from low and high socioeconomic status. Dev Psychopathol 13:653-676.

88. Belojevic G, Jakovljevic B, Stojanov V, Paunovic K, Ilic J. 2008. Urban road-traffic noise and blood pressure and heart rate in preschool children. Environ Int 2001; 34:226-231.

89. Belojevic G, Saric-Tanaskovic M. Prevalence of arterial hypertension and myocardial infarction in relation to subjec-tive ratings of traffic noise exposure. $\mathrm{N}$ oise $\mathrm{H}$ ealth 2002; 4:33-37.

90. Gee GC, Takeuchi DT. Traffic stress, vehicular burden, and well-being: a multilevel analysis. Soc Sci M ed 2004; 59(2):405-414.

91. Subramanian SV, Chen J, Rehropf DH, Waterman PD, Krieger N. Racial disparities in context: a multilevel analysis of neighborhood variations in poverty and excess mortality among black populations in M assachusetts. Am J Public H ealth 2005; 95(2):260265.

92. Zhu Y, Hinds WC, Kim S, Sioutas C. Concentration and size distribution of ultrafine particles near a major high-way. J Air Waste Manag Assoc 2002; 52:1032-1041.

93. Clougherty JE, Levy JI, Hynes HP, Spengler JD. A longitudinal analysis of the efficacy of environmental interventions on asthma-related quality of life and symptoms among children in urban public housing. J Asthma 2006; 43:335-343.

94. Cory-Slechta DA, Virgolini MB, Thiruchelvam M, Weston DD, Bauter MR. Maternal stress modulates the effects of developmental lead exposure. Environ Health Perspect 2004; 112:717-730.

95. Rossi-George A, Virgolini MB, Weston DD, CorySlechta DA. Alterations in glucocorticoid negative feedback following maternal $\mathrm{Pb}$, prenatal stress, and the combination: a potential biological unifying mechanism for their corresponding disease profiles. Toxicol Appl Pharmacol 2009; 234(1):117-127.

96. Hotsenpiller G, Williams J. Conditioned fear and analgesia to conspecific odors: benzodiazepine and 5-HT1A agonists. Psychobiology 1996; 24(2):118126.

97. Luciano D, Lore R. Aggression and social experience in domesticated rats. J Comp Physiol Psych 1975; 88:917-923.

98. Clougherty JE, Rossi CA, Lawrence J, Long M, Diaz E, Koutrakis P, Godleski JJ. Social stress and susceptibility to concentrated particulate air polIution (CAPs) in rats [Abstract]. Epidemiology 2008; 19(6):S163.
99. Fiedler $\mathrm{N}$, Laumbach $\mathrm{R}$, Kelly-M $\mathrm{CN}$ eil $\mathrm{K}$, Lioy $\mathrm{P}$, Fan Z, Zhang J, Ottenweller J, Ohman-Strickland P, Kipen $\mathrm{H}$. Health effects of a mixture of indoor air volatile organics, their ozone oxidation products, and stress. Environ Health Perspect 2005; 113:15421548.

100. Colligan MJ. The psychological effects of air pollution. Bull NY Acad M ed 1981; 57(10):1014-1026.

101. Strahilevitz M, Strahilevitz A, Miller J. Air pollution and the admission rate of psychiatric patients. Am J Psychiatry 1979; 136:205-207.

102. Rotton J, Frey J, Barry T. The air pollution experience and physical aggression. J Appl Soc Psychol 1979; 9:397-412.

103. Horvath SV, Dahms TE. Carbon monoxide and human vigilance: a deleterious effect of present urban concentra-tions. Arch Environ Health 1971; 23:343-347.

104. Putz V, Johnson BL, Setzer JV. Effects of CO on Vigilance Performance. NIOSH Publication 77-124. Washington, D.C.: Government Printing Office; 1977.

105. Hore T, Gibson DE. Ozone exposure and intelligence tests. Arch Environ Health 1968; 17:77-79.

106. Jones JW. Adverse emotional reactions of nonsmokers to secondary cigarette smoke. Environ Psychol Nonverbal Behav 1978; 3:125-127.

107. Evans GW, Jacobs SV. Air pollution and human behavior. J Soc Issues 1981; 37:95-125.

108. Lagerwerff JM. Prolonged ozone inhalation and its effect on visual parameters. Aerosp M ed 1963; 34:479-486.

109. Forsberg B, Stjernberg N, Wall S. People can detect poor air quality well below guideline concentrations: a preva-lence study of annoyance reactions and air pollution from traffic. Occup Environ Med 1997; 54(1):44-48.

110. Piro F, Madsen C, Naess O, Nafstad P, Claussen B. A comparison of self reported air pollution problems and GIS-modeled levels of air pollution in people with and without chronic diseases. Environ $\mathrm{H}$ ealth 2008; 28:7:9

111. Elliot SJ, Taylor SM, Walter S. Modelling psychosocial effects of exposure to solid waste facilities. Soc Sci M ed 1993; 37(6):791-804.

112. Eyles J, Taylor SM, Johnson N. Worrying about waste: living close to solid waste disposal facilities in southern Ontario. Soc Sci M ed 1993; 37(6):805812.

113. Lupien SJ, King S, Meaney MJ, M CEwen BS. Child's stress hormone levels correlate with mother's socio-economic status and depressive state. Biol Psychiatry 2000; 48:976-980.

114. Gouveia N, Bremner S, Novaes M. Association between ambient air pollution and birth weight in São Paulo, Brazil. J Epidemiol Community Health 2004; 58:11-17.

115. Viltart O, Vanbesien-M aillot CC. Impact of prenatal stress on neuroendocrine programming. Scientific World Journal 2007; 7:1493-1537.

116. Cicchetti D, Walker EF. Stress and development: bio-logical and psychological consequences [Editorial]. Dev Psychopathology 2001; 13:413-418. 
117. M cEwen BS. Understanding the potency of stressful early life experiences on brain and body function. M etabolism 2008; 57(supp 2):S11-S15.

118. Krieger N. Gender and racial discrimination: risk factors for high blood pressure? Soc Sci M ed 1990; 12:1273-1281.

119. National Environmental Justice Advisory Council. Ensuring Risk Reduction in Communities with Multiple Stressors: Environmental Justice and Cumulative Risks/Impacts. New Orleans, LA: Cumulative Risks/Impacts Work Group, National Environmental Justice Advisory Council; 2004.

120. Borrell LN, Kiefe Cl, Williams DR, Diez-Roux AV, Gordon-Larsen P. Self-reported health, perceived racial discrimination, and skin color in African Americans in the CARDIA study. Soc Sci M ed 2006; 63:1415-1427.

21. Clark R, Anderson NB, Clark VR, Williams DR. Racism as a stressor for African Americans: a biopsychosocial model. Am Psychol 1999; 54(10):805816.

122. Krieger $\mathrm{N}$, Sidney S. Racial discrimination and blood pressure: the CARDIA Study of young black and white adults. Am J Public H ealth 1996; 86:13701378.

123. Kwate NOA, Valdimarsdottir HB, Guevarra JS, Bovbjerg $D H$. Experiences of racist events are associated with negative health consequences for African American women. J Natl Med Assoc 2003; 95(6):450-460

124. Landrine $\mathrm{H}$, Klonoff EA. The Schedule of Racist Events: a measure of racial discrimination and a study of its nega-tive physical and mental health consequences. J Black Psychol 1996; 22:144-168.

125. Thompson VLS. Perceived experiences of racism as stressful life events. Community $\mathrm{M}$ en $\mathrm{H}$ ealth J 1996; 32:223-233.

126. Lauderdale DS. Birth outcomes for Arabic-named women in California before and after September 11. Demography 2006; 43(1):185-201.

127. Singh GK, Hiatt RA. Trends and disparities in socio-economic and behavioral characteristics, life expectancy, and cause-specific mortality of nativeborn and foreign-born populations in the U nited States, 1979-2003. Int J Epidemiol 2006; 35(4):903919.

128. Krieger N. Stormy weather: race, gene expression, and the science of health disparities. Am J Public $H$ ealth 2005; 95(12):2155-2160.

129. Geronimus A. The weathering hypothesis and the health of African-American women and infants: evidence and speculations. Ethn Dis 1992; 2:207-221.

130. Goodman E, McEwen BS, Dolan LM, SchaferKalkoff T, Adler NE. Social disadvantage and adolescent stress. J Adolesc Health 2005; 37:484-492.

131. M erritt M, Bennett G, Williams R, Sollers J, Thayer J. Low educational attainment, John Henryism, and cardiovascular reactivity to and recovery from personally relevant stress. Psychosom M ed 2004; 66(1):49-55.

132. James SA, Van Hoewyk J, Belli RF, Strogatz DS, Williams DR, Raghunathan TE. Life-course socioeconomic position and hypertension in AfricanAmerican men: The Pitt County Study. Am J Public Health 2006; 96(5):812-817.
133. Pappas G, Queen S, Hadden W, Fisher G. The increasing disparity and mortality between socioeconomic groups in the United States, 1960 and 1986. N Eng J Med 1993; 329:103-109.

134. David RJ, Collins JW. Differing birth weight among infants of U.S.-born blacks, African-born blacks, and U.S.-born whites. N Engl J Med 1997; 337:12091214.

135. Luginaah IN, Fung KY, Gorey KM, Webster G, Wills C. Association of ambient air pollution with respiratory hospitalization in a government-designated "area of concern": the case of Windsor, Ontario. Environ Health Perspect 2005; 113:290-296.

136. Oftedal B, Brunekreef B, Nystad W, Madsen C, Walker SE, Nafstad P. Residential outdoor air pollution and lung function in schoolchildren. Epidemiology 2008; 19(1):129-137.

137. Rojas-M artinez $R$, Perez-Padilla $R$, Olaiz-Fernandez $G$, M endoza-Alvarado $L, M$ oreno- $M$ acias $H$, Fortoul T, McDonnell W, Loomis D, Romieu I. Lung function growth in children with long-term exposure to air pollutants in Mexico City. Am J Respir Crit Care M ed 2007; 176:377-384.

138. Rosenlund M, Forastiere F, Porta $D$, De Sario $M$, Badaloni C, Perucci CA. Traffic-related air pollution in relation to respiratory symptoms, allergic sensitization, and lung function in school children. Thorax 2009; 64(7):573-580.

139. Kim CS, Hu SC. Regional deposition of inhaled particles in human lungs: comparison between men and women. J Appl Physiol 1998; 84(6):1834-1844.

140. Kohlhaufl M, Brand P, Scheuch G, Meyer TS, Schulz $\mathrm{H}, \mathrm{H}$ aussinger $\mathrm{K}$. Increased fine particle deposition in women with asymptomatic nonspecific airway hyper-responsiveness. Am J Respir Crit Care Med 1999; 159(3):902-906.

141. Arbuckle TE. Are there sex and gender differences in acute exposure to chemicals in the same setting? Environ Res 2006; 101:195-204.

142. Messing K, Stellman JM. Sex, gender, and women's occupational health: the importance of considering mechanism. Environ Res 2006; 101:146-162.

143. McConnell R, Berhane K, Gilliand F, London SJ, Islam T, Gauderman WJ, Avol E, Margolis HG, Peters JM . Asthma in exercising children exposed to ozone: a cohort study. Lancet 2002; 359:386391.

144. Dietrich DF, Gemperil A, Gaspoz J-M, Schindler C, Liu SL-J, Gold DR, Schwartz J, Rochat T, Barthélémy JC, Pons $M$, Roche $F$, Probst $H$ ensch $N M$, Bridevaux PO, Gerbase M W, Neu U, AckermannLiebrich U, SAPALDIA Team. Differences in heart rate variabil-ity associated with long-term exposure to NO2. Environ Health Perspect 2008; 116:1357-1361.

145. Jedrychowski W, Krzyzanowski M. Ventilatory lung function and chronic chest symptoms among the inhabitants of urban areas with various levels of acid aerosols: prospective study in Cracow. Environ Health Perspect 1989; 79:101-107.

146. Sundaram V, Helweg-Larsen K, Laursen B, Bjerregaard $P$. Physical violence, self rated health, and morbidity: is gen-der significant for victimisation? J Epidemiol Community Health 2004; 58:65-70. 
147. Taylor SE, Klein LC, Lewis BP, Gruenewald TL, Gurung RAR, Updegraff JA. Biobehavioral responses to stress in females; tend-and-befriend, not fightor-flight. Psychol Rev 2000; 107(3):411-429.

148. Kan H, London SJ, Chen G, Zhang Y, Song G, Zhao $N$, Jiang $L$, Chen $B$. Season, sex, age, and education as modifiers of the effects of outdoor air pollution on daily mortality in Shanghai, China: The Public Health and Air Pollution in Asia (PAPA) Study. Environ Health Perspect 2008; 116:1183-1188.

149. Adler NE, Boyce T, Chesney MA, Cohen S, Folkman S, Kahn RL, Syme SL. Socioeconomic status and health. The challenge of the gradient. Am Psychol 1994; 49(1):15-24.

150. Fernald LCH, Burke HM, Gunnar MR. Salivary cortisol levels in children of low-income women with high depressive symptomatology. Dev Psychopathol 2008; 20:423-436.

151. Ronsaville DS, M unicchi G, Laney C, Cizza G, Meyer SE, Haim A, Radke-Yarrow M, Chrousos G, Gold PW, M artinez PE. M aternal and environmental factors influence the hypothalmic-pituitaryadrenal axis response to corticotropin-releasing hormone infusion in offspring of mothers with or without mood disorders. Dev Psychopathol 2006; 18:173-194.

152. Dowd J, Goldman N. Do biomarkers of stress mediate the relation between socioeconomic status and health?J Epidemiol Community H ealth 2006; 60:633-639.

153. Macleod J, Davey Smith G. Psychosocial factors and public health: a suitable case for treatment? J Epidemiol Community Health 2003; 57(8):565-570.

Received 23 January 2009

Accepted 12 M ay 2009 